\title{
Decreasing the indications for radical nephrectomy: a study of multifocal renal cell carcinoma
}

\author{
Maximiliano Sorbellini ${ }^{1}$ and Gennady Bratslavsky ${ }^{2}$ * \\ 1 Urology Research and Consultancy, Miami Beach, FL, USA \\ ${ }^{2}$ Department of Urology, State University of New York Upstate Medical University, Syracuse, NY, USA
}

\section{Edited by:}

Brian Lane, Spectrum Health, USA

Reviewed by:

Nicholas Glenn Cost, Cincinnati Children's Hospital Medical Center, USA

Christopher Whelan, Spectrum Health, USA

\section{${ }^{*}$ Correspondence:}

Gennady Bratslavsky, Department of Urology, State University of New York Upstate Medical University, Syracuse, NY 13210, USA.

e-mail: bratslag@upstate.edu
Multifocal renal cell carcinoma (RCC) has been reported in $5-25 \%$ of cases worldwide. Although management of patients with multifocal RCC has not been clearly defined, presence of multifocal renal masses in one kidney and a normal contralateral kidney has often been considered a reason for performing radical nephrectomy. This study reviews the world literature to provide an accurate estimate of the prevalence of multifocal RCC and evaluates the oncologic outcomes of multifocal RCC after exclusion of patients with known hereditary and familial renal syndromes. A PubMed search of the literature was performed for articles in the English language using the following terms for the query: "multifocal RCC," "multifocality and RCC," "multicentric RCC," or "bilateral RCC." The references of the published articles were also reviewed for additional publications. Articles that did not specifically exclude patients with familial RCC or known hereditary RCC syndromes were excluded for estimation of multifocality prevalence and oncologic outcomes. After applying our exclusion criteria, nine articles were selected and form the basis of the current analysis. Weighted averages were used to calculate the prevalence of multifocality. Multifocal RCC was found in $6.8 \%$ of cases (373 of 5433 patients). Ipsilateral multifocality was found in $6.8 \%$ of cases. Bilateral multifocality was found in $11.7 \%$ of cases. Of all cases reported in this study, only $10 \%$ underwent partial nephrectomy. The rest of the study cohort underwent radical nephrectomy. The review of the literature showed that the use of nephron-sparing techniques in patients with multifocal disease did not compromise oncologic outcomes, despite the need for reoperation in certain cases. In conclusion, multifocal RCC remains a prevalent entity. Most clinicians still prefer to perform radical nephrectomies in these patients despite proven equivalent oncologic outcomes compared to nephron-sparing techniques. Urologists should be aware of these data when proposing treatment options to patients with multifocal RCC.

Keywords: multifocality, multifocal RCC, bilateral RCC, nephron-sparing surgery, partial nephrectomy, outcomes

\section{INTRODUCTION}

Identifying patients with multifocal renal cell carcinoma (RCC) is of major importance due to its influence on the treatment strategy, timing, and treatment modality used in such patients. Management of multifocal RCC has been a source of multiple debates for several reasons. First of all, it remains one of the relative contraindications to partial nephrectomy (Campbell et al., 2007) as it causes many urologists to think twice before embarking on a nephron-sparing approach, either due to technical considerations or oncologic concerns (Vogelzang, 2006). Second, radical nephrectomy would prevent the patient from potentially requiring a future repeat renal surgery for new or recurrent lesions in the same renal unit; a procedure known to be technically challenging. Third, in the absence of specific genetic studies to identify the clonal origin of every lesion, some may feel uncomfortable assigning ipsilateral or contralateral recurrences as de novo satellite tumors rather than intra-renal metastases. Finally, the relative paucity of reported outcomes for patients treated for multifocal RCC has not allowed for a wide acceptance of the nephron-sparing approaches as a preferred treatment modality.
Multifocal RCC has been reported in 5-25\% of cases in the world literature (Kinouchi et al., 1999; Wunderlich et al., 1999). This incongruent variability in values is likely due to a variety of reasons. First, some of those studies have not excluded all patients with hereditary or familial RCC, known to be multifocal in nature (Delakas et al., 2002; Klatte et al., 2007; Linehan et al., 2009; Sargin et al., 2009). Second the quality of imaging modalities as well as radiologic evaluation used in different eras or locations may have contributed to the variability in detection of multifocal RCC found by different groups (Schlichter et al., 2000). Third, the pathological assessment of specimens has also varied in the different reports. Some investigators examined the renal surface only, others examined the kidney after stripping its capsule, while others examined the kidneys after they had been serially sectioned. Finally, the absence of accepted criteria used to define multifocality may have also resulted in variations of the estimated prevalence of multifocal RCC in the literature.

In the present report, we aim to examine differences in multifocality definitions and detection strategies used in published studies to identify the prevalence of "sporadic" multifocal RCC. 
We also examine oncologic outcomes of surgeries for sporadic multifocal RCC.

\section{METHODS}

\section{SYSTEMATIC REVIEW OF THE LITERATURE}

A PubMed search of the literature was performed independently by each author for articles in the English language using the following terms for the query: "multifocal RCC," "multifocality and RCC," "multicentric RCC," or "bilateral RCC.” The references of the published articles were also reviewed for additional publications. We excluded articles that did not specifically exclude patients with familial RCC or known hereditary renal cancer syndromes, and those articles in which the prevalence for multifocal RCC could not be determined. After applying our exclusion criteria, nine articles were selected and these form the basis for the current analysis. The oncologic outcomes were then tabulated from the articles that met our inclusion criteria. Inclusion and exclusion criteria were decided before the literature search was initiated.
For the purpose of this study, multifocality was defined as the presence of two or more tumors present in the same renal unit, regardless of histology or timing of detection in the absence of extra-renal metastatic disease. The prevalence of multifocal RCC was calculated using weighted averages after dividing the number of cases with multifocality by the number of total cases with RCC (solitary and multifocal RCC).

\section{RESULTS}

The prevalence of non-hereditary sporadic multifocal RCC was calculated to be $6.8 \%$ (Table 1). The occurrence of bilateral multifocal tumors was found to be $11.7 \%$. As shown in Table 2 a subset analysis of our cohort shows that metastasis-free survival and overall-survival are similar to those reported by other series (Table 3). Furthermore, oncologic outcomes are similar for patients treated for solitary as well as for multifocal tumors (in sporadic population). Finally, Table 3 shows excellent renal functional preservation in the setting of multiple surgeries on the same renal unit (in hereditary population).

Table 1 | List of peer reviewed articles included for analysis.

\begin{tabular}{|c|c|c|c|c|c|c|c|}
\hline Reference & $\begin{array}{l}\text { Serial } \\
\text { section? }\end{array}$ & $\begin{array}{l}\text { Total } \\
\text { cases }\end{array}$ & Total multifocal & RN (\%) & PN (\%) & $\begin{array}{l}\text { Ipsilateral } \\
\text { multifocal (\%) }\end{array}$ & $\begin{array}{l}\text { Bilateral } \\
\text { multifocal (\%) }\end{array}$ \\
\hline Tsivian et al. (2010) & Yes & 560 & $81(14.4 \%)$ & 560 & 0 & $81(14.4 \%)$ & $\mathrm{n} / \mathrm{a}$ \\
\hline Crispen et al. (2008b) & $\mathrm{n} / \mathrm{a}$ & 1113 & $60(5.4 \%)$ & $599(53.8 \%)$ & $514(46.2 \%)$ & $60(5.4 \%)$ & $8 / 37(21 \%)$ \\
\hline Krambeck et al. (2008) & $\mathrm{n} / \mathrm{a}$ & 140 & $\mathrm{n} / \mathrm{a}$ & $114(81.4 \%)$ & $26(19.6 \%)$ & $\mathrm{n} / \mathrm{a}$ & $11(7.85 \%)$ \\
\hline Richstone et al. (2004) & Yes & 1071 & $57(5.3 \%)$ & 1071 & 0 & $57(5.3 \%)$ & $28(2.6 \%)$ \\
\hline Dimarco et al. (2004) & $\mathrm{n} / \mathrm{a}$ & 2373 & $130(5.4 \%)$ & 2373 & 0 & $130(5.4 \%)$ & $\mathrm{n} / \mathrm{a}$ \\
\hline Bilen et al. (1999) & Yes & 40 & $4(10 \%)$ & 40 & 0 & $4(10 \%)$ & $\mathrm{n} / \mathrm{a}$ \\
\hline Kinouchi etal. (1999) & Yes & 124 & $23(18.5 \%)$ & 124 & 0 & $23(18.5 \%)$ & $\mathrm{n} / \mathrm{a}$ \\
\hline Oya etal. (1995) & Yes & 108 & $7(6.5 \%)$ & 108 & 0 & $7(6.5 \%)$ & $\mathrm{n} / \mathrm{a}$ \\
\hline \multirow[t]{3}{*}{ Whang et al. (1995) } & Yes & 44 & $11(25 \%)$ & 44 & 0 & $11(6.5 \%)$ & $\mathrm{n} / \mathrm{a}$ \\
\hline & & & Weighted average: & & & Weighted average: & Weighted average: \\
\hline & & & $6.82 \%$ & & & $6.82 \%$ & $11.72 \%$ \\
\hline
\end{tabular}

Table 2 | Oncologic outcomes for the study cohort.

\begin{tabular}{|c|c|c|c|c|c|c|c|c|c|c|c|}
\hline \multirow[t]{2}{*}{ Reference } & \multirow[t]{2}{*}{$\begin{array}{l}\text { Number } \\
\text { of cases }\end{array}$} & \multirow[t]{2}{*}{$\begin{array}{l}\text { Number of } \\
\text { multifocal } \\
\text { kidneys }\end{array}$} & \multirow[t]{2}{*}{$\begin{array}{l}\text { Median } \\
\text { follow-up } \\
\text { (year) }\end{array}$} & \multicolumn{2}{|c|}{$\begin{array}{c}\text { Metastasis-free } \\
\text { survival at } \\
5 \text { years }(\%)\end{array}$} & \multicolumn{2}{|c|}{$\begin{array}{c}\text { Cancer-specific } \\
\text { survival at } \\
5 \text { years }(\%)\end{array}$} & \multicolumn{2}{|c|}{$\begin{array}{l}\text { Overall-survival } \\
\text { at } 5 \text { years (\%) }\end{array}$} & \multicolumn{2}{|c|}{$\begin{array}{c}\text { Contralateral } \\
\text { tumor-free survival } \\
\text { at } 5 \text { years }(\%)\end{array}$} \\
\hline & & & & $\begin{array}{l}\text { Solitary } \\
\text { tumors }\end{array}$ & $\begin{array}{l}\text { Multifocal } \\
\text { tumors }\end{array}$ & $\begin{array}{l}\text { Solitary } \\
\text { tumors }\end{array}$ & $\begin{array}{l}\text { Multifocal } \\
\text { tumors }\end{array}$ & $\begin{array}{l}\text { Solitary } \\
\text { tumors }\end{array}$ & $\begin{array}{l}\text { Multifocal } \\
\text { tumors }\end{array}$ & $\begin{array}{l}\text { Solitary } \\
\text { tumors }\end{array}$ & $\begin{array}{l}\text { Multifocal } \\
\text { tumors }\end{array}$ \\
\hline Crispen etal. (2008b) & 1113 & 60 & 6.1 & 97.6 & 96.5 & 98.7 & 96.2 & 84.4 & 84 & 99.1 & 94.4 \\
\hline Krambeck etal. (2008) & 140 & 140 & 6.1 & $\mathrm{n} / \mathrm{a}$ & $\mathrm{n} / \mathrm{a}$ & $\mathrm{n} / \mathrm{a}$ & $\begin{array}{l}90.5(95.8 \\
\text { if NSS)* }\end{array}$ & $\mathrm{n} / \mathrm{a}$ & $\mathrm{n} / \mathrm{a}$ & $\mathrm{n} / \mathrm{a}$ & $\mathrm{n} / \mathrm{a}$ \\
\hline Richstone et al. (2004) & 1071 & 57 & 3.4 & 73.2 & 71.5 & $\mathrm{n} / \mathrm{a}$ & $\mathrm{n} / \mathrm{a}$ & 79.3 & 75.2 & 84.9 & 82.5 \\
\hline
\end{tabular}

n/a, not available.

${ }^{*}$ CCS at 5 years for cases treated with radical nephrectomy or nephron-sparing surgery are 90.5 and $95.8 \%$, respectively. 
Table 3 | Functional outcomes post-nephron-sparing techniques in hereditary multifocal RCC.

\begin{tabular}{llll}
\hline Reference & $\begin{array}{l}\text { Number } \\
\text { of cases }\end{array}$ & $\begin{array}{l}\text { Median follow- } \\
\text { up (month) }\end{array}$ & $\begin{array}{l}\text { Change in serum } \\
\text { creatinine (mg/d) }\end{array}$ \\
\hline Bratslavsky etal. (2008) & 13 & 25 & +0.2 \\
Johnson etal. (2008) & 51 & 56 & +0.19 \\
Herring etal. (2001) & 62 & 30 & +0.01 \\
Liu etal. (2010) & 25 & 60 & +0.2 \\
\hline
\end{tabular}

\section{DISCUSSION}

We found that the prevalence of sporadic multifocal RCC was $6.8 \%$ (Table 1). This number is intriguing as the $6.8 \%$ rate of multifocality found in this study correlates well with the historic incidence of ipsilateral recurrence after partial nephrectomy of 4-9\% (Kinouchi et al., 1999; Crispen et al., 2008a; Peycelon et al., 2009). This appears to suggest that many of the lesions that have been considered recurrences or intra-renal metastasis in the past might have just been incipient multifocal lesions not identified pre-operatively or during the actual surgical procedure. Notably, many studies have shown that most satellite lesions, in excess of $60 \%$, are not detected by modern preoperative imaging studies (Baltaci et al., 2000; Crispen et al., 2008b; Krambeck et al., 2008).

\section{DEFINING MULTIFOCAL RCC}

One of the major problems in the study of multifocal RCC is precisely how to define multifocality itself. What defines a multifocal tumor? Is it simply the presence of another lesion within the same renal unit (Miyake et al., 1998; Junker et al., 2002)? Must the second lesion by necessity be malignant? Must there be a minimum amount of parenchyma in between primary and satellite lesions in order for multifocality to exist (Sargin et al., 2009)? Must all lesions share the same histology? Does the presence of a contralateral tumor also define multifocal disease (Bani-Hani et al., 2005)? Does the contralateral kidney need to contain multiple tumors for it to be multifocal? And is the multifocality on one kidney related to the multifocality on the opposite kidney? Furthermore, how can we even know if a second lesion within the same renal unit, or on the contralateral kidney for that matter, is a new de novo lesion unrelated to the primary tumor, or a local recurrence or metastasis from the primary lesion?

Unfortunately, without performing a specific genetic study designed to evaluate the clonal origin of each mass found it is often difficult to determine whether a second renal lesion implies that patients have multifocal, recurrent, or metastatic disease (Miyake et al., 1998; Junker et al., 2002; Blute et al., 2003). Because of our inability to answer these questions, in the present study, we defined multifocality in a broad manner in order to incorporate all the data available to us. Thus, we defined multifocality as the presence of two or more tumors present in the same renal, regardless of histology or timing of detection, in the absence of extra-renal metastatic disease in patients not known to have familial disease or hereditary syndromes. We acknowledge that some patients in our study may nevertheless be part of obscure or yet-to-be-discovered RCC syndromes. This is because the diagnosis of hereditary or familial RCC is not always straight forward and while certain syndromes are well know to all urologists, others, such as familial renal syndromes seen in patients with tuberous sclerosis or succinate dehydrogenase deficiency, for example, are not. In terms of histology, from our earlier studies of hereditary renal tumors we know that multiple tumors of various histologies can coexist within the same renal unit. We also know that the same genetic abnormality can lead to both benign and malignant renal lesions within the same kidney and that these lesions can also be found bilaterally and metachronously. For example, patients with von HippelLindau (VHL) syndrome are prone to develop bilateral multifocal recurrent clear cell RCC; patients with hereditary papillary RCC (HPRCC) develop bilateral papillary type 1 RCC; hereditary leiomyomatosis RCC (HLRCC) patients tend to form aggressive papillary type 2 RCC and Birt-Hogg-Dubé (BHD) patients may develop a whole spectrum of tumors from benign oncocytomas to chromophobe RCC to aggressive clear cell RCC (Toro et al., 2008). Furthermore, as our knowledge of the genetic basis of renal neoplasias grows we keep finding new types of hereditary syndromes, such as the less well understood syndromes of tuberous sclerosis and succinate dehydrogenase B deficiency (Sudarshan and Linehan, 2006).

\section{HISTORICAL PERSPECTIVE AND CURRENT APPROACH TO MULTIFOCAL RCC}

Ever since Robson's 1969 article (Robson et al., 1969) suggested that radical nephrectomy should be the treatment of choice for patients with renal tumors, that practice has become standard of care, in particular for kidneys harboring multifocal RCC. Of note, Robson et al.'s (1969) conclusion was based on a report of outcomes of a few selected patients. During the next 3040 years, in large part due to the knowledge gained through patients who underwent partial nephrectomies for imperative indications, Robson's model has come under question. Initial reports about the technical feasibility of nephron-sparing procedures performed for small renal masses and subsequent reports of its oncologic efficacy, similar to that of radical nephrectomy, have slowly built a foundation for a wider utilization of partial nephrectomy (Russo et al., 2002). Additionally, with the understanding that RCC was not a single entity but a conglomeration of neoplastic processes, each with its own biological identity and aggressiveness (Kovacs etal., 1997), the field of urology has slowly realized that perhaps a one-operation-fits-all model was not the best way to approach every type of renal tumor. Thus, the indications for elective partial nephrectomy began to expand (Russo et al., 2002), resulting in a much larger cohort of cases to be analyzed and compared to outcomes of radical nephrectomy.

We now know that, despite previous teachings, not only tumors smaller than $4 \mathrm{~cm}$ but also larger than $4 \mathrm{~cm}$ are amenable to nephron-sparing techniques (Russo, 2007). We also know that stage-by-stage the oncologic outcomes seem to be similar between partial nephrectomy and radical nephrectomy cohorts (Bratslavsky et al., 2008; Johnson et al., 2008; Breau et al., 2010; Liu etal., 2010). Furthermore, recent data have confirmed 
that patients undergoing radical nephrectomies for RCC are at higher risk not only of developing renal insufficiency (Huang etal., 2006; Sorbellini etal., 2006) but more ominously, to die of non-cancer-related causes, such as cardiovascular events, compared to patients undergoing nephron-sparing techniques (Huang etal., 2009). Additionally, data from patients treated with multiple partial nephrectomies for hereditary and familial RCC syndromes indicate that the oncologic outcome is not altered in those patients when they undergo multiple repeated partial nephrectomies (Gupta etal., 2010). Finally, National Cancer Institute data on repeat surgical interventions on a same kidney indicate that kidneys can withstand multiple injuries due to surgical procedures and renal function is usually well-preserved (Table 3), preventing patients from having to undergo dialysis or renal transplantation (Bratslavsky et al., 2008; Gupta et al., 2010).

Despite all this information, indications for partial nephrectomy still need to be enumerated and radical nephrectomies are still favored by a large number of urologists even for small solitary renal tumors of less than $4 \mathrm{~cm}$ in maximum diameter (Russo, 2006). In fact, at the present time there are no NCCN Guidelines regarding multifocal RCC tumors. Perhaps a better treatment approach for sporadic multifocal RCC would be performing the same type of surgery as for patients with familial or hereditary RCC syndromes, i.e., resection of all detectable renal lesions via nephron-sparing techniques as they become apparent and reach a certain size (Walther et al., 1999). The latter is supported by the fact that: (a) there is no oncologic benefit to performing radical nephrectomy versus partial nephrectomy, (b) there are no data proving that newly discovered post-surgical lesions are indeed recurrences or metastases after partial nephrectomy, (c) at least $20 \%$ of RCC lesions are either benign or indolent in nature, and (d) the data showing that losing a renal unit puts patients at higher risk not only of developing renal insufficiency but also of death from noncancer-related causes (Crispen et al., 2008a). Finally, as the data presented in this study show, a significant number of patients with multifocal RCC will have renal lesions in the contralateral kidney, possibly necessitating surgery at a later date, increasing their chances of becoming anephric, had radical nephrectomy previously performed.

\section{REFERENCES}

Baltaci, S., Orhan, D., Soyupek, S., Beduk, Y., Tulunay, O., and Gogus, O. (2000). Influence of tumor stage, size, grade, vascular involvement, histological cell type and histological pattern on multifocality of renal cell carcinoma. J. Urol. 164, 36-39.

Bani-Hani, A. H., Leibovich, B. C., Lohse, C. M., Cheville, J. C., Zincke, H., and Blute, M. L. (2005). Associations with contralateral recurrence following nephrectomy for renal cell carcinoma using a cohort of 2,352 patients. J. Urol. 173, 391-394.

Bilen, C. Y., Mahalati, K., Ozen, H., Aki, F. T., Ilyas, C., and Kendi, S. (1999). Multicentricity in renal cell carcinoma. Int. Urol. Nephrol. 31, 295-299.

Blute, M. L., Itano, N. B., Cheville, J. C., Weaver, A. L., Lohse, C. M., and Zincke, H. (2003). The effect of bilaterality, pathological features and surgical outcome in nonhereditary renal cell carcinoma. J. Urol. 169, 1276-1281.

Bratslavsky, G., Liu, J. J., Johnson, A. D., Sudarshan, S., Choyke, P. L., Linehan, W. M., and Pinto, P. A. (2008). Salvage partial nephrectomy for hereditary renal cancer: feasibility and outcomes. J. Urol. 179, 67-70.

Breau, R. H., Crispen, P. L., Jimenez, R. E., Lohse, C. M., Blute, M.

\section{CLINICAL IMPLICATIONS}

Identifying patients at higher risk for metastatic disease and those who are likely to fail local therapy is indeed of paramount importance. Nevertheless, treating patients with overkill surgeries under the presumption that more is better puts patients at risk not only for renal insufficiency but also for cardiovascular disease and death from non-cancer-related causes (Sorbellini et al., 2006; Huang et al., 2009). Radical nephrectomy may not only be unnecessary in these patients but it may also prevent those patients from future treatments (e.g., targeted therapies) that require a normal renal function to qualify for them. Although we strongly advocate appropriate surgery for local control of renal lesions, with negative surgical margins, the reader should also be aware of recent data showing that positive surgical margins do not jeopardize survival outcomes in patients undergoing nephron-sparing techniques (Yossepowitch et al., 2008). Therefore, we encourage surgeons to attempt nephron-sparing surgery whenever technically feasible and, in cases of multifocal disease.

\section{LIMITATIONS OF THE STUDY}

The present study has several limitations. It is possible that some of the patients included in our analysis were undiagnosed hereditary RCC cases. We only reported results on patients treated surgically and may have potentially missed those with metastatic disease that were not included in the original publications.

\section{CONCLUSION}

Multifocal RCC remains an underappreciated and misunderstood entity with a prevalence of at least $6 \%$. Bilateral multifocal disease is found in $11.7 \%$ of cases. The presence of multiple renal tumors in one kidney appears to increase the risk of having renal lesions in the contralateral kidney. Twenty percent of multifocal RCC are benign or indolent in nature. Stage-by-stage, oncologic outcome appears similar for patients treated with radical or partial nephrectomy. Resection of multiple renal lesions from the same renal unit in a single setting is feasible and may allow for excellent preservation renal function. Radical nephrectomy, in the context of RCC, appears to increase the risk of renal insufficiency and death from unrelated causes. Nephron-sparing techniques should thus be considered whenever technically feasible, in particular in cases of multifocal RCC.

L., and Leibovich, B. C. (2010). Outcome of stage T2 or greater renal cell cancer treated with partial nephrectomy. J. Urol. 183, 903-908.

Campbell, S. C., Novick, A. C., and Bukowski, R. M. (2007). "Renal tumours," in Campbell-Walsh Urology, 9th Edn., eds A. J. Wein, L. R. Kavoussi, Novick, A. C., Partin, A. W. and Peters, C. A. (Philadelphia: W.B. Saunders), 1600

Crispen, P. L., Boorjian, S. A., Lohse, C. M., Sebo, T. S., Cheville, J. C., Blute, M. L., and Leibovich, B. C. (2008a). Outcomes following partial nephrectomy by tumor size. J. Urol. 180, 1912-1917.
Crispen, P. L., Lohse, C. M., and Blute, M. L. (2008b). Multifocal renal cell carcinoma: clinicopathologic features and outcomes for tumors $\leq 4 \mathrm{~cm}$. Adv. Urol. 2008, 518091 .

Delakas, D., Karyotis, I., Daskalopoulos, G., Terhorst, B., Lymberopoulos, S., and Cranidis, A. (2002). Nephronsparing surgery for localized renal cell carcinoma with a normal contralateral kidney: a European three-center experience. Urology 60, 998-1002.

Dimarco, D. S., Lohse, C. M., Zincke, H., Cheville, J. C., and Blute, M. L. (2004). Long-term survival of patients with unilateral sporadic multifocal renal cell carcinoma 
according to histologic subtype compared with patients with solitary tumors after radical nephrectomy. Urology 64, 462-467.

Gupta, G. N., Peterson, J., Thakore, K. N., Pinto, P. A., Linehan, W. M., and Bratslavsky, G. (2010). Oncological outcomes of partial nephrectomy for multifocal renal cell carcinoma greater than $4 \mathrm{~cm}$. J. Urol. 184, 59-63.

Herring, J. C., Enquist, E. G., Chernoff, A., Linehan, W. M., Choyke, P. L., and Walther, M. M. (2001). Parenchymal sparing surgery in patients with hereditary renal cell carcinoma: 10-year experience. J. Urol. 165, 777-781.

Huang, W. C., Elkin, E. B., Levey, A. S., Jang, T. L., and Russo, P. (2009). Partial nephrectomy versus radical nephrectomy in patients with small renal tumors - is there a difference in mortality and cardiovascular outcomes? J. Urol. 181, 55-61; discussion 61-62.

Huang, W. C., Levey, A. S., Serio, A. M., Snyder, M., Vickers, A. J., Raj, G. V., Scardino, P. T., and Russo, P. (2006). Chronic kidney disease after nephrectomy in patients with renal cortical tumours: a retrospective cohort study. Lancet Oncol. 7, 735-740.

Johnson, A., Sudarshan, S., Liu, J., Linehan, W. M., Pinto, P. A., and Bratslavsky, G. (2008). Feasibility and outcomes of repeat partial nephrectomy. J. Urol. 180, 89-93; discussion 93.

Junker, K., Thrum, K., Schlichter, A., Muller, G., Hindermann, W., and Schubert, J. (2002). Clonal origin of multifocal renal cell carcinoma as determined by microsatellite analysis. J. Urol. 168, 2632-2636.

Kinouchi, T., Mano, M., Saiki, S. Meguro, N., Maeda, O., Kuroda, M., Usami, M., and Kotake, T. (1999). Incidence rate of satellite tumors in renal cell carcinoma. Cancer 86, 2331-2336.

Klatte, T., Wunderlich, H., Patard, J. J., Kleid, M. D., Lam, J. S., Junker, K., Schubert, J., Böhm, M., Allhoff, E. P., Kabbinavar, F. F., Crepel, M., Cindolo, L., De La Taille, A., Tostain, J., Mejean, A., Soulie, M., Bellec, L., Bernhard, J. C., Ferriere, J. M., Pfister, C., Albouy, B., Colombel, M., Zisman, A. Belldegrun, A. S., and Pantuck, A. J. (2007). Clinicopathological features and prognosis of synchronous bilateral renal cell carcinoma: an international multicentre experience. $B J U$ Int. 100, 21-25.

Kovacs, G., Akhtar, M., Beckwith, B. J., Bugert, P., Cooper, C. S., Delahunt B., Eble, J. N., Fleming, S., Ljungberg, B., Medeiros, L. J., Moch, H. Reuter, V. E., Ritz, E., Roos, G., Schmidt, D., Srigley, J. R., Störkel, S., van den Berg, E., and Zbar, B. (1997). The Heidelberg classification of renal cell tumours. J. Pathol. 183, 131-133.

Krambeck, A., Iwaszko, M., Leibovich, B., Cheville, J., Frank, I., and Blute, M. (2008). Long-term outcome of multiple ipsilateral renal tumours found at the time of planned nephron-sparing surgery. BJU Int 101, 1375-1379.

Linehan, W. M., Pinto, P. A., Bratslavsky, G., Pfaffenroth, E., Merino, M., Vocke, C. D., Toro, J. R., Bottaro, D., Neckers, L., Schmidt, L. S., and Srinivasan, R. (2009). Hereditary kidney cancer: unique opportunity for disease-based therapy. Cancer 115(Suppl.), 2252-2261.

Liu, N. W., Khurana, K., Sudarshan S., Pinto, P. A., Linehan, W. M., and Bratslavsky, G. (2010). Repeat partial nephrectomy on the solitary kidney: surgical, functional and oncological outcomes. J. Urol. 183, 1719-1724.

Miyake, H., Nakamura, H., Hara, I., Gohji, K., Arakawa, S., Kamidono, S., and Saya, H. (1998). Multifocal renal cell carcinoma: evidence for a common clonal origin. Clin. Cancer Res. 4, 2491-2494.

Oya, M., Nakamura, K., Baba, S., Hata, J., and Tazaki, H. (1995). Intrarenal satellites of renal cell carcinoma: histopathologic manifestation and clinical implication. Urology 46, 161-164.

Peycelon, M., Hupertan, V., Comperat, E., Renard-Penna, R., Vaessen, C. Conort, P., Bitker, M. O., ChartierKastler, E., Richard, F., and Rouprêt, M. (2009). Long-term outcomes after nephron sparing surgery for renal cell carcinoma larger than $4 \mathrm{~cm}$. J. Urol. 181, 35-41.

Richstone, L., Scherr, D. S., Reuter, V. R., Snyder, M. E., Rabbani, F., Kattan, M. W., and Russo, P. (2004). Multifocal renal cortical tumors: frequency, associated clinicopathological features and impact on survival. $J$. Urol. 171(Pt 1), 615-620.
Robson, C. J., Churchill, B. M., and Anderson, W. (1969). The results of radical nephrectomy for renal cell carcinoma. J. Urol. 101, 297-301.

Russo, P. (2006). Open partial nephrectomy: an essential contemporary operation. Nat. Clin. Pract. Urol. 3, 2-3

Russo, P. (2007). Open partial nephrectomy: an essential operation with an expanding role. Curr. Opin. Urol. 17, 309-315.

Russo, P., Goetzl, M., Simmons, R., Katz, J., Motzer, R., and Reuter, V. (2002). Partial nephrectomy: the rationale for expanding the indications. Ann. Surg. Oncol. 9, 680-687.

Sargin, S. Y., Ekmekcioglu, O., Arpali, E., Altinel, M., and Voyvoda, B. (2009). Multifocality incidence and accompanying clinicopathological factors in renal cell carcinoma. Urol. Int. 82 324-329.

Schlichter, A., Schubert, R., Werner W., Zermann, D. H., and Schubert, J. (2000). How accurate is diagnostic imaging in determination of size and multifocality of renal cell carcinoma as a prerequisite for nephronsparing surgery? Urol. Int. 64 , 192-197.

Sorbellini, M., Kattan, M. W., Snyder, M. E., Hakimi, A. A., Sarasohn, D. M., and Russo, P. (2006). Prognostic nomogram for renal insufficiency after radical or partial nephrectomy. J. Urol. 176, 472-476; discussion 476. Sudarshan, S., and Linehan, W. M. (2006). Genetic basis of cancer of the kidney. Semin. Oncol. 33, 544-551.

Toro, J. R., Wei, M. H., Glenn, G. M., Weinreich, M., Toure, O., Vocke, C., Turner, M., Choyke, P., Merino, M. J., Pinto, P. A., Steinberg, S. M., Schmidt, L. S., and Linehan, W. M. (2008). BHD mutations, clinical and molecular genetic investigations of Birt-Hogg-Dubé syndrome: a new series of 50 families and a review of published reports. J. Med. Genet. 45, 321-331.

Tsivian, M., Moreira, D. M., Caso, J. R., Mouraviev, V., Madden, J. F. Bratslavsky, G., Robertson, C. N., Albala, D. M., and Polascik, T. J. (2010). Predicting occult multifocality of renal cell carcinoma. Eur. Urol. $58,118-126$.

Vogelzang, N. (2006). Comprehensive Textbook of Genitourinary Oncology, 3rd Edn. Philadelphia: Lippincott Williams \& Wilkins.
Walther, M. M., Choyke, P. L., Glenn, G., Lyne, J. C., Rayford, W., Venzon, D., and Linehan, W. M. (1999). Renal cancer in families with hereditary renal cancer: prospective analysis of a tumor size threshold for renal parenchymal sparing surgery. J. Urol. 161, 1475-1479.

Whang, M., O’Toole, K., Bixon, R., Brunetti, J., Ikeguchi, E., Olsson, C. A., Sawczuk, T. S., and Benson, M. C. (1995). The incidence of multifocal renal cell carcinoma in patients who are candidates for partial nephrectomy. J. Urol. 154, 968-970; discussion 970-971.

Wunderlich, H., Schlichter, A., Zermann, D., Reichelt, O., Kosmehl, H., and Schubert, J. (1999). Multifocality in renal cell carcinoma: a bilateral event? Urol. Int. 63, 160-163.

Yossepowitch, O., Thompson, R. H., Leibovich, B. C., Eggener, S. E., Pettus, J. A., Kwon, E. D., Herr, H. W., Blute, M. L., and Russo, P. (2008). Positive surgical margins at partial nephrectomy: predictors and oncological outcomes. J. Urol. 179, 2158-2163.

Conflict of Interest Statement: The authors declare that the research was conducted in the absence of any commercial or financial relationships that could be construed as a potential conflict of interest.

Received: 12 March 2012; paper pending published: 09 April 2012; accepted: 16 July 2012; published online: 06 August 2012.

Citation: Sorbellini $M$ and Bratslavsky $G$ (2012) Decreasing the indications for radical nephrectomy: a study of multifocal renal cell carcinoma. Front. Oncol. 2:84. doi: 10.3389/fonc.2012.00084

This article was submitted to Frontiers in Genitourinary Oncology, a specialty of Frontiers in Oncology.

Copyright (c) 2012 Sorbellini and Bratslavsky. This is an open-access article distributed under the terms of the Creative Commons Attribution License, which permits use, distribution and reproduction in other forums, provided the original authors and source are credited and subject to any copyright notices concerning any third-party graphics etc. 